\title{
Going-concern opinions, auditor switching, and the self-fulfilling prophecy effect examined in the regulatory context of Belgium
}

Citation for published version (APA):

Vanstraelen, A. (2003). Going-concern opinions, auditor switching, and the self-fulfilling prophecy effect examined in the regulatory context of Belgium. Journal of Accounting, Auditing \& Finance, 18(2), $231-253$. https://doi.org/10.1177/0148558X0301800204

Document status and date:

Published: 01/01/2003

DOI:

10.1177/0148558X0301800204

Document Version:

Publisher's PDF, also known as Version of record

Please check the document version of this publication:

- A submitted manuscript is the version of the article upon submission and before peer-review. There can be important differences between the submitted version and the official published version of record.

People interested in the research are advised to contact the author for the final version of the publication, or visit the DOI to the publisher's website.

- The final author version and the galley proof are versions of the publication after peer review.

- The final published version features the final layout of the paper including the volume, issue and page numbers.

Link to publication

\footnotetext{
General rights rights.

- You may freely distribute the URL identifying the publication in the public portal. please follow below link for the End User Agreement:

www.umlib.nl/taverne-license

Take down policy

If you believe that this document breaches copyright please contact us at:

repository@maastrichtuniversity.nl

providing details and we will investigate your claim.
}

Copyright and moral rights for the publications made accessible in the public portal are retained by the authors and/or other copyright owners and it is a condition of accessing publications that users recognise and abide by the legal requirements associated with these

- Users may download and print one copy of any publication from the public portal for the purpose of private study or research.

- You may not further distribute the material or use it for any profit-making activity or commercial gain

If the publication is distributed under the terms of Article $25 \mathrm{fa}$ of the Dutch Copyright Act, indicated by the "Taverne" license above, 


\title{
Going-Concern Opinions, Auditor Switching, and the Self-Fulfilling Prophecy Effect Examined in the Regulatory Context of Belgium
}

\author{
ANN VANSTRAELEN*
}

\begin{abstract}
Previous studies have demonstrated that auditors are reluctant to issue going-concern opinions. Some suggest this reluctance is strategic and stems from the auditor's desire to avoid loss of clients or reputation. This paper investigates the threat of loss resulting from auditor switching and client bankruptcy in the regulatory context of Belgium. Belgium requires companies to engage an audit firm for a three-year period. Consequently, the client's threat of switching auditors is potentially more credible in the third year than in the first two years.

The empirical results support the hypothesis that going-concern opinions significantly increase the probability of bankruptcy. Thus, goingconcern reports remain relevant even in a country where debt financing is dominant. In addition, clients are four times more likely to switch auditors at the end of the mandatory term if they receive a going-concern opinion in the final year of the term relative to the previous two years. This strongly suggests that mandatory terms influence the association between going-concern opinions and auditor switching.
\end{abstract}

\section{Introduction}

The auditing literature documents the reluctance by auditors to issue goingconcern opinions (Hopwood et al. [1991]; Citron and Taffler [1992]; Carcello et al. [1997]). As a possible explanation for the reluctance, research cites strategic auditor or client behavior (Krishnan and Krishnan [1996]; Matsumura et al. [1997]). Essentially, the auditor faces an economic trade-off in deciding to issue a goingconcern opinion. On the one hand, auditors not issuing a going-concern opinion

*Universiteit Antwerpen and Universiteit Maastricht

I wish to thank the members of my doctoral commission for their comments on earlier versions of this paper, in particular Ann Jorissen, Willem Buijink, John Christensen, and Ignace De Beelde. The helpful suggestions of the participants of the EAA conference in Munich 2000, my colleagues at the Universiteit Maastricht, Nico Valckx, and two anonymous referees are also gratefully acknowledged. A special word of gratitude is due to Peter Joos and Steven Maijoor. 
face costs of exposure to third-party lawsuits and loss of reputation (Krishnan and Krishnan [1996]). On the other hand, auditors issuing a going-concern opinion face costs of loss of clients and/or loss of reputation (Teoh [1992]; Nogler [1995]). Empirical studies examining the costs of audit loss are limited, especially in the context of Continental European countries. In my study, I examine the relation between going-concern opinions and audit loss in a Continental European business environment, Belgium.

Audit loss can occur when the client switches auditors after the client company survives the going-concern opinion, or when the client goes bankrupt. My paper contributes to the literature by examining empirically the impact of a going-concern opinion both on auditor switching and client bankruptcy and in the regulatory context of Belgium. Being a Continental European country, Belgium exhibits business environment characteristics different from those found in Anglo-American countries. First, accounting is governed by a legal framework, banks and other financial institutions play a central role in corporate financing, and financial reporting is strongly influenced by tax considerations and is creditor-oriented (Lefebvre and Flower [1994]; Block and Jorissen [1995]). Second, litigation rates in Continental Europe are rather low in comparison with the United States and the United Kingdom (Kinney [1994]; Gietzmann and Quick [1998]). Third, in contrast to many countries, Belgium exhibits the additional characteristic of an audit mandate of three years, renewable without limitation, but always for a period of three years. The renewable audit mandate of three years in Belgium allows me to examine whether the decision to issue a going-concern opinion early-versus later during the mandate-affects auditor switching differently.

I find results consistent with the hypothesis that a going-concern opinion significantly increases the likelihood of impending bankruptcy. In addition, I find companies surviving a going-concern opinion are significantly more likely to switch auditors in the subsequent year. I also find the effect of a going-concern opinion on auditor switching only exists when the auditor issues the going-concern opinion in the last year of the official mandate; a going-concern opinion in the first two years of the official mandate does not appear to incrementally explain auditor switching. My results, therefore, suggest mandatory terms influence the association between going-concern opinions and auditor switching and potentially affect auditor independence.

My study contributes to the auditing literature by providing evidence on the contentious issue of the self-fulfilling prophecy effect, which comes down to the belief that a client will go bankrupt as a result of a going-concern opinion. In addition, the results reveal the mitigating role mandatory terms can play in dampening clients' threats to switch auditors when they are dissatisfied with the auditor's report.

This paper is organized as follows. First, I review the relevant previous literature. Second, I describe the audit market in Belgium that provides an institutional framework for interpreting the empirical results of the study. Third, I formulate the hypotheses. Fourth, I describe the research design. Fifth, I present the results of 
the study. Finally, I discuss the results, draw conclusions, address the limitations of the study, and give suggestions for further research.

\section{Previous Literature}

A going-concern opinion can trigger the end of an auditor-client relationship. Audit loss subsequent to the issuance of a going-concern opinion can result from client bankruptcy or auditor switching.

\subsection{Self-Fulfilling Prophecy Effect}

The belief that a client will go bankrupt as a result of a going-concern opinion is known in the literature as the self-fulfilling prophecy effect (Mutchler [1984]). Mutchler reports, on the basis of interviews, that auditors admit that they take the potential impact of a going-concern opinion on the client into account. However, the majority of partners interviewed do not believe in the self-fulfilling prophecy effect. According to Boritz (1991), the self-fulfilling prophecy effect is a "myth." The game-theoretic model of Tucker and Matsumura (1998) predicts auditors issue fewer going-concern opinions when such opinions are self-fulfilling. However, the experimental results do not confirm the economic prediction. A possible explanation is that auditors exhibit risk aversion and attempt to avoid negative payoffs resulting from reporting errors.

Empirical research on the existence of the self-fulfilling prophecy effect finds conflicting results. No supportive evidence is found by Citron and Taffler (1992), Louwers et al. (1999), or Citron and Taffler (2001). In contrast, evidence consistent with the self-fulfilling prophecy effect is provided by George et al. (1996) and Pryor and Terza (2001). Given the mixed results of prior empirical research, further research on the self-fulfilling prophecy effect is warranted.

Louwers et al. (1999) sum up some key technical problems of examining the self-fulfilling prophecy effect: First, it is difficult to disentangle a going-concern opinion from other indicators of financial distress. Second, evidence that goingconcern opinions are significant in predicting bankruptcy could arise because the opinion is a self-fulfilling prophecy or because the auditor possesses private information that is subsumed in the going-concern opinion and correctly anticipates bankruptcy. Third, archival data limit the possibility to fully assess the impact of a going-concern opinion on a company's future operations. Indeed, it is impossible to apply dissimilar treatments to similar companies, nor is it possible to observe whether a bankrupt company would still be in existence had the auditor decided against issuing a going-concern opinion.

This paper addresses the first two limitations in the following way. First, in contrast to the study of Louwers et al. (1999), my study includes companies that either did or did not receive a going-concern opinion. Moreover, other indicators of financial distress besides the going-concern opinion variable are included in the bankruptcy-prediction model. This allows me to examine whether a going-concern 
opinion incrementally explains bankruptcy, while controlling for other indicators of financial distress. Second, I test for a correlation between unobserved bankruptcy determinants and the going-concern opinion variable. The test consists of computing the generalized residuals of the going-concern opinion variable and including them as an additional explanatory variable in the bankruptcy model.

\subsection{Auditor Switching}

Early empirical research uses open-ended questionnaires to infer companies' reasons for auditor switching. The following reasons are often cited: audit fee, responsiveness of the auditor to the client, merger and acquisition, rotation policy, occurrence of management changes, lack of a good working relationship, reporting disagreements, and financial distress (Fried and Schiff [1981]; DeAngelo [1982]; Eichenseher and Shields [1983]; Menon and Schwartz [1985]; Addams and Davis [1994]; Schwartz and Soo [1996]).

Empirical research further examines the association between either client or auditor characteristics and observed auditor selection, or changes in these characteristics and observed auditor changes (Beattie and Fearnley [1995]). Research findings show that the likelihood of auditor switching is negatively related to the length of the auditor-client relationship (Levinthal and Fichman [1988]), and positively related to initial public offerings (Menon and Williams [1991]), agency conflicts (DeFond [1992]), and changes in client size (Haskins and Williams [1990]).

The receipt of a qualified opinion appears to increase the likelihood of auditor switching (Chow and Rice [1982]; Craswell [1988]; Citron and Taffler [1992]; Krishnan and Stephens [1995]; Lennox [2000]), although this finding is not supported by Menon and Schwartz (1985). Auditor conservatism, resulting in a tendency to issue qualified reports, motivates auditor changes as well (Krishnan [1994]; DeFond and Subramanyam [1998]). The experimental results of Tucker and Matsumura (1998) suggest clients switch more often if the auditor's goingconcern opinion increases the prospect of business termination. Krishnan et al. (1996) find that companies with high switch threats are more likely to receive modified reports. Lennox (2000) provides evidence that auditor switching increases the likelihood of a change in audit report.

In sum, prior research examining the relationship between auditor reporting and auditor switching has tested different influences on audit reporting. This paper examines the association between going-concern opinions and auditor switching in Belgium where audit firms are engaged for three-year periods. I expect that the client's threat of switching auditors is more credible in the third year relative to the first two years.

\section{The Audit Market in Belgium}

Belgian Company Law governs the statutory audit of companies. The General Meeting of Shareholders appoints the statutory auditor on the recommendation of 
the Board of Directors. All Belgian companies that employ on average more than one hundred workers have a works' council. It is a body with parity representation of employers and employees and its purpose is to implement social legislation. The works' council has the right to refuse the appointment of the nominee auditor and defend this position in court. Auditors are appointed for a term of three years that is renewable without limitation for further three-year periods. Dismissal of the auditor during his mandate is only allowed under exceptional circumstances (e.g. physical incapacity or negligence resulting in a loss of confidence). Likewise, resignation of the auditor during his mandate is restricted, except for serious personal reasons. The General Meeting has to be informed in writing of the reasons for the resignation, and the resignation has to be approved by the works' council, if established, and for companies under prudential control by the supervisory organ. ${ }^{1}$

In principle, the audit fee remains fixed during the mandate of three years. However, the General Meeting of Shareholders is allowed to stipulate an index fee adjustment. Breesch (2001) provides evidence that audit mandates in Belgium are frequently renewed. Her results suggest the average audit tenure is twenty years and the resignation rate of Belgian auditors is low.

Auditors in Belgium are subject to a strict code of ethics and auditing standards. Many of the regulations aim to protect auditor independence (Buijink et al. [1996]). Belgium has a proportional liability system. The client company, shareholders, and interested third parties can undertake legal action against the auditor until five years after the issue of the auditor's report. Litigation rates in Belgium are low, as is typical for countries that have government-prescribed conservative accounting standards, and where the major providers of capital are banks or the government (Mueller et al. [1994]).

Belgian audit regulation requires the auditor to ascertain whether the goingconcern assumption is acceptable and to what extent existing going-concern problems are adequately disclosed in the financial statements. Depending on the situation, Belgian audit regulation requires the following types of audit reports: an unqualified report with explanatory paragraph when the going-concern uncertainty has been correctly disclosed in the financial statements ${ }^{2}$; a qualified opinion in case of inappropriate information in the financial statements; a disclaimer of opinion in case of lack of information to evaluate the going-concern status of the company; and an adverse opinion if the going-concern assumption is no longer appropriate.

1. Banks and insurance companies are under the prudential control of the Financial Supervisory Board. This means that these companies are submitted to stricter audit regulations. One of the tasks of the Financial Supervisory Board consists of the appointment and approval of resignation of the statutory auditor.

2. During the period under study, 1992-1996, the "unqualified audit opinion with explanatory paragraph" was not yet recognized by the Belgian Institute of Auditors. However, 4 out of the 1,176 companies in our sample did receive an unqualified opinion that mentions going-concern problems. These four reports are coded as disclosing a going-concern uncertainty. 


\section{Development of Hypotheses}

This paper examines whether auditors in Belgium suffer economic loss as a result of issuing going-concern opinions. Audit loss can result from client bankruptcy or auditor switching. In this respect, I test two hypotheses.

Auditors defend their reluctance to issue a going-concern opinion because they fear the self-fulfilling prophecy effect. In the words of P. Behets, former chairman of the Belgian Institute of Auditors: "Every warning could mean the end of the company and damage all interested parties. When the management of the company with going-concern problems does not seem to undertake any actions to restore their financial position, the auditor's decision to issue a going-concern opinion becomes even more sensitive" (De Financieel Economische Tijd [1996]). The first hypothesis deals with the impact of a going-concern opinion on the likelihood of client bankruptcy. The hypothesis formulated in alternative form is as follows:

$H_{1}$ : Going-concern opinions increase the likelihood of bankruptcy, controlling for factors that simultaneously influence the likelihood of bankruptcy and the likelihood of a going-concern opinion.

The second hypothesis deals with the impact of a going-concern opinion on the probability of auditor switching when the client survives. Since auditors in Belgium are appointed for a minimum and renewable period of three years, I examine whether the impact of a going-concern opinion in the audit report issued in the first two years of the audit mandate differs from one issued in the last year of the audit mandate. The hypothesis formulated in alternative form is as follows:

$\mathrm{H}_{2}$ : Going-concern opinions increase the likelihood of auditor switching more in the last year of the audit mandate than in the first two years.

\section{Research Design}

\subsection{Sample}

The empirical analysis uses data over the period 1992-1996 taken from CDROMs of the Belgian National Bank. The CD-ROMs contain the annual accounts of all Belgian companies that have to publish their financial statements (in general, all limited liability companies). For each year, three samples are selected. The first sample is from the population of large companies that went bankrupt. ${ }^{3}$ The bankrupt sample does not contain financial institutions, utility companies, or listed firms. ${ }^{4}$

3. The Law on Bookkeeping considers a company to be large if it exceeds more than one of the following criteria: (1) average number of persons employed on annual basis is fifty; (2) annual turnover, exclusive VAT, $€ 6,250,000$; (3) balance sheet total, $€ 3,125,000$, or whose average number of employees exceeds one hundred.

4. The number of listed firms in Belgium is low and during the period under study none of the listed firms went bankrupt. 
The second sample contains financially stressed, non-bankrupt, large companies. Based on common criteria in the literature (Kida [1980]; Mutchler [1985]; Hopwood et al. [1994]), I consider a company as financially stressed if it either has a loss from operations, a bottom line loss, negative retained earnings, or a quick ratio smaller than one in the previous two years. The third sample is a control sample and contains financially non-stressed, non-bankrupt, large companies. Menon and Schwartz (1985) stress the importance of matching control groups by year, industry, and size. Therefore, the three samples are matched by year, industry (using NACE codification, 4 digits $^{5}$ ), and size (based on total assets). The sample design of this study is similar to the U.K. study of Citron and Taffler (1992). ${ }^{6}$

The three samples contain 392 observations each or, in total, 1,176 observations. The financial statements, the audit report, and the annual report of the Board of Directors are collected and examined for each company in the sample. Table 1 illustrates the sample proportions and the type of audit report issued. The table shows that only 37 percent of bankrupt companies receive a going-concern opinion in the audit report one year prior to bankruptcy.

\subsection{Bankruptcy Model}

To analyze the impact of a going-concern opinion on the probability of company failure, I distinguish between initial and repeated going-concern opinions. It could be argued that it is unreasonable to interpret the occurrence of bankruptcy after several years of repeated going-concern opinions as a self-fulfilling prophecy (Pryor and Terza [2001]). However, if repeated going-concern opinions have no effect on the probability of bankruptcy, this would weaken the claim that auditors suffer losses as a result of issuing going-concern opinions. I identify companies with repeated going-concern opinions by examining the three previous audit reports of all companies that receive a going-concern opinion.

To estimate the likelihood of bankruptcy after receipt of an initial goingconcern opinion (IGCO) and a repeated going-concern opinion (RGCO), I use logistic regression analysis. An initial and repeated going-concern opinion are the two main variables of interest in the bankruptcy model. To control for the fact that company failure could also have been predicted based on publicly available financial and non-financial information, $I$ include the following control variables in the model.

First, I include the financial condition of the firm as a control variable. I measure the financial condition by the general discriminant score (DSCORE) of a

5. NACE is the abbreviation of "Nomenclature Generale des Activités Economiques dans l'Union Européenne" or "General Name for Economic Activities in the European Union." The NACE-code system is based on the European standard for industry classifications.

6. The sample design is different from similar research in the United States where matched-pairs sampling often is used: a sample with unqualified opinions and a sample with modified opinions. This sampling approach is not possible in Belgium since Belgian databases do not allow to search directly on the type of audit report issued. 
TABLE 1

\section{Sample Proportions and Type of Audit Reports Issued}

\begin{tabular}{|c|c|c|c|}
\hline Audit Report & $\begin{array}{c}\text { Sample } \\
\text { Bankrupt Firms } \\
(\mathrm{N}=392)\end{array}$ & $\begin{array}{l}\text { Sample Financially } \\
\text { Stressed, Non- } \\
\text { Bankrupt Firms } \\
\quad(\mathrm{N}=392)\end{array}$ & $\begin{array}{l}\text { Sample Financially Non- } \\
\text { Stressed, Non-Bankrupt } \\
\text { Firms }(\mathrm{N}=392)\end{array}$ \\
\hline Unqualified audit report & $163(41.6 \%)$ & $293(74.8 \%)$ & $370(94.4 \%)$ \\
\hline $\begin{array}{l}\text { Disclosure of going-concern } \\
\text { uncertainty: }\end{array}$ & $145(37 \%)$ & $53(13.5 \%)$ & $0(0 \%)$ \\
\hline qualified opinion & $102(70 \%)$ & $49(92 \%)$ & \\
\hline disclaimer of opinion & $35(24 \%)$ & $4(8 \%)$ & \\
\hline adverse opinion & $8(6 \%)$ & $0(0 \%)$ & \\
\hline $\begin{array}{l}\text { No disclosure of going-concern } \\
\text { uncertainty: }\end{array}$ & $84(21.4 \%)$ & $46(11.7 \%)$ & $22(5.6 \%)$ \\
\hline qualified opinion & $60(71 \%)$ & $34(74 \%)$ & $17(77 \%)$ \\
\hline disclaimer of opinion & $21(25 \%)$ & $12(26 \%)$ & $5(23 \%)$ \\
\hline adverse opinion & $3(4 \%)$ & $0(0 \%)$ & $0(0 \%)$ \\
\hline
\end{tabular}

standard bankruptcy prediction model developed for Belgian companies. ${ }^{7}$ I expect that a lower DSCORE results in a higher likelihood of bankruptcy.

Second, I include the time lag between the closing of the fiscal year and the submission of the financial statements to the Belgian National Bank as a control variable. In this respect, I make a distinction between a delay of the annual general meeting of shareholders (GMDELAY) and a submission lag (SUBMLAG) of the financial statements to the Belgian National Bank. Belgian Company Law requires that the annual general meeting take place within six months after the closing of the fiscal year. Companies have to submit the financial statements to the Belgian National Bank within thirty days after the annual general meeting of shareholders. I expect that problem companies delay their annual general meeting and exceed the required submission time of the financial statements and consequently are more likely to go bankrupt.

Third, I include the location of the company (LOC) as a control variable: Flanders or Wallonia. National statistics show the bankruptcy ratio, that is, the number of bankruptcies divided by the number of establishments, is higher in the southern part of Belgium-Wallonia-compared to the northern part-Flanders. The same applies to the number of bankruptcies divided by the total number of

7. The DSCORE is calculated from the general multiple linear discriminant model, developed for Belgian companies, consisting of the following ratios: accumulated profit (loss) and reserves/total liabilities; taxes and social security charges/short-term external liabilities; cash/restricted current assets; work in progress and finished goods/restricted current assets; short-term financial debts/short-term external liabilities. The optimal cut-off point of DSCORE $=0.1304$ (Ooghe, Joos, and de Bourdeaudhuij [1995]). The bankruptcy models developed in Belgium do not make a distinction between industries (Ooghe et al. [1995]). It would be beyond the scope of this paper to develop different bankruptcy models for different industries. 
companies. ${ }^{8}$ Therefore, the probability of bankruptcy of a company located in Wallonia is higher than the probability of bankruptcy in Flanders. An economic explanation for this higher bankruptcy ratio is the structure of the economy in Wallonia, which is characterized by traditional industries and a weaker demand, resulting in lower economic growth rate.

Finally, I include bad news disclosed in the annual report of the Board of Directors as a control variable. Belgian Company Law prescribes the type of information the annual report of the Board of Directors must contain. Two statutory paragraphs are of particular importance for assessing the likelihood of failure, namely paragraph 2 "important events after the closing of the fiscal year" (PAR2) and paragraph 3 "circumstances that can influence significantly the development of the company" (PAR3). Next to these two paragraphs, Belgian Company Law requires the annual report to disclose if Article 103/104 of Belgian Company Law (ART103/104) that signals financial distress is applicable. ${ }^{9}$ Finally, the annual report can provide additional information (ADINFO) besides that required by law. I distinguish three types of news elements that could be relevant for the prediction of bankruptcy: general information on the economic situation, a description of the prospects of the company, and a description of actions and/or measures that will be taken. I expect that bad news in the second and third statutory paragraphs, disclosure that Article 103/104 is applicable, and voluntary disclosure of additional bad news increases the likelihood of company failure. Table 2 summarizes and defines the variables used in the bankruptcy model.

Using logistic regression, I estimate the following bankruptcy model:

$$
\begin{aligned}
\text { BANKRUPT }_{\mathrm{i}}= & \beta_{0}+\beta_{1} \text { IGCO }_{\mathrm{i}}+\beta_{2} \text { RGCO }_{\mathrm{i}}+\beta_{3} \text { DSCORE }_{\mathrm{i}} \\
& +\beta_{4} \text { GMDELAY }_{\mathrm{i}}+\beta_{5} \text { SUBMLAG }_{\mathrm{i}}+\beta_{6} \text { LOC }_{\mathrm{i}} \\
& +\beta_{7} \text { PAR2 }_{\mathrm{i}}+\beta_{8} \text { PAR }_{\mathrm{i}}+\beta_{9} \text { ADINFO }_{\mathrm{i}} \\
& +\beta_{10} \text { ART103/104 }_{\mathrm{i}}+\varepsilon_{\mathrm{i}}
\end{aligned}
$$

Maddala (1991) argues that using a choice-based sample to estimate a logit model requires no weighting procedure. The coefficients of the explanatory variables are not affected by the unequal sampling rates, it is only the constant term that is affected.

8. The bankruptcy ratio, defined as the number of bankruptcies divided by the number of establishments, is in Wallonia on average 0.28 and in Flanders 0.22 during the period 1991-1996. The number of bankruptcies divided by the total number of companies follows the same pattern, on average 0.020 in Wallonia and 0.017 in Flanders during the period 1991-1996 (calculations based on data provided by the NIS).

9. Article (103, Alarmprocedure) states: "If net assets are less than $50 \%$ of the subscribed capital, the Board of Directors is required to convene the members of the general meeting, who must decide on the basis of the Board's reorganisation plans whether or not to continue the entity. The diagnosis has to take into account the specific characteristics of the entity at the closing date of the fiscal year, as well as events between this closing date and the date on which the Board of Directors approves the annual statements and submits them to the general meeting." Article (104) states that "if net assets are below the minimal amount any interested party may appeal to the court to dissolve the company." 
TABLE 2

Model Variables and Measurement-Bankruptcy Model

\begin{tabular}{lll}
\hline Variables & Description & Measurement \\
\hline BANKRUPT $_{i}:$ & $\begin{array}{l}\text { Bankrupt company or non- } \\
\text { bankrupt company in year t }\end{array}$ & $\begin{array}{l}\text { Binary variable: BANKRUPT }=1 \text { in case of } \\
\text { bankrupt company, else BANKRUPT }\end{array}$ \\
\hline & Independent: \\
\hline
\end{tabular}

$\mathrm{IGCO}_{1}$ : Initial going-concern opinion to client $\mathrm{i}$ in year $\mathrm{t}-1$

$\mathrm{RGCO}_{1}$ : $\quad$ Repeated going-concern opinion to client $i$ in year $t-1$

DSCORE $_{i}$ Discriminant score of company $\mathrm{i}$ in year $\mathrm{t}-1$

GMDELAY: Submission delay of the annual accounts of year $t-1$ of company $i$ to the shareholders

SUBMLAG: Submission lag of the annual accounts of year $t-1$ of company $i$ to the Belgian National Bank

$\mathrm{LOC}_{i}$ : $\quad$ Location of client company in year $\mathrm{t}-1$ : Flanders or Wallonia

PAR2 ${ }_{i}: \quad$ Information in paragraph 2 of the annual report of the Board of Directors in year $\mathrm{t}-1$ of company $\mathrm{i}$ "Important Events after the Closing of the Fiscal Year"

PAR3: $\quad$ Information in paragraph 3 of the annual report of the Board of Directors in year $\mathrm{t}-1$ of company $\mathrm{i}$ "Circumstances That Can Influence Significantly the Development of the Company"

$\mathrm{ADINFO}_{i}$ : $\quad$ Additional information given in the annual report of the Board of Directors in year $\mathrm{t}-1$ of company $\mathrm{i}$ : general information on the economic situation; description of the prospects for the company; description of actions, measures that will be taken

ART103/104: Application of Article 103/104 of the Belgian Company Law is disclosed in the annual report of the Board of Directors in year $t-1$ of company $\mathrm{i}$
Binary variable: $\mathrm{IGCO}_{i}=1$ in case of an initial going-concern opinion, else $\mathrm{IGCO}_{i}=0$

Binary variable: $\mathrm{RGCO}_{i}=1$ in case of a repeated going-concern opinion, else $\mathrm{RGCO}_{i}=0$

General discriminant score (D-score) of a standard bankruptcy model developed for Belgian companies.

The time in months between the balance sheet date and the date of the annual general meeting.

The time in days between the date of the annual general meeting and the submission date of the annual accounts and audit report to the Belgian National Bank.

Binary variable: $\mathrm{LOC}_{\mathrm{i}}=1$ in case company is located in Wallonia, $\mathrm{LOC}_{\mathrm{i}}=0$ in case company is located in Flanders

Binary variable: $\mathrm{PAR}_{\mathrm{i}}=1$ in case important events after the closing of the fiscal year have occurred and are disclosed in the annual report of the Board of Directors, else PAR $2_{i}=0$

Binary variable: $P A R 3_{i}=1$ in case the annual report of the Board of Directors describes circumstances that can influence significantly the development of the company, else PAR $3_{1}=0$

Ordinal variable: $\mathrm{ADINFO}_{4}=0$ in case no additional bad news or good news is disclosed; AD$\mathrm{INFO}_{1}=1,2$, or 3 in case bad news is disclosed on one, two, three information elements, respectively.

In case of a mixture of good and bad news elements, only the bad news elements count for coding the $\mathrm{ADINFO}_{\mathrm{i}}>0$.

Binary variable: ART103/104 $=1$ in case the application of the Article(s) is disclosed, else ART103/104 $=0$ 


\subsection{Switching Model}

For the second research hypothesis, the sample of bankrupt companies cannot be used since the decision to switch auditors is no longer relevant. Therefore, the analyses are done on the samples of financially stressed and non-stressed surviving companies. Both samples contain 392 observations each, so the total number of observations is 784. Data on the history and length of the auditor-client relationship are retrieved from the CD-ROMs of the Belgian National Bank. For each observation, the following information is collected: the start of the auditor-client relationship; number of renewals of the audit mandate; and the end of the last audit mandate when the client switches auditors. Given the audit mandate of three years, audit firm switch data are analyzed over a period of three years following the audit report. For example, if the audit report of company X was issued in 1994 (year t), then it is checked whether company X switches auditors in 1995 (year $t+1$ ), 1996 (year $t+2)$, or 1997 (year $t+3)$. In total, 9.31\% (=73/784) of the companies switch auditors. Table 3 summarizes and defines the dependent and independent variables.

The dependent binary variable is "SWITCH," coded 1 if a company switches auditors in the next mandate period (year $\mathrm{t}+1$, year $\mathrm{t}+2$, or year $\mathrm{t}+3$, depending on whether the year of the examined audit report was respectively the last, second, or first year of the audit mandate) or coded 0 in the case of no switch. The independent variables of interest are going-concern opinions in the first, second, or last year of the incumbent auditor's official mandate. A distinction is also made between initial and repeated going-concern opinions, since initial going-concern opinions may have a bigger impact on auditor switching. This results in the following six variables: initial going-concern opinion in the first (IGCOY1), second (IGCOY2), or final year (IGCOY3) of the auditor's mandate and repeated going-concern opinion in the first (RGCOY1), second (RGCOY2), or final year (RGCOY3).

To reduce the likelihood of correlated omitted variables, I include three control variables in the model that can affect the auditor switch decision. ${ }^{10}$ First, a switch of auditor can reflect financial distress (Menon and Schwartz [1985]). I measure financial distress by the general discriminant score (DSCORE) of a standard bankruptcy prediction model developed for Belgian companies.

Second, most auditor switching studies include an auditor size variable, Big 6 auditor or non-Big 6 auditor (B6) (Krishnan [1994]). ${ }^{11}$ The B6 variable is coded 1 if the incumbent (potentially outgoing) auditor is a Big 6 firm. I posit no direction for the B6 variable. On the one hand, the B6 variable represents both audit quality and auditor reputation, which would result in a negative sign (Krishnan et al. [1996]). On the other hand, searching for a more flexible auditor is easier if you

10. This paper does not focus on situational or contextual variables that may influence auditor switching. firms.

11. My sample relates to the period 1992-1996. During this period there were still six Big audit 
TABLE 3

Model Variables and Measurement-Auditor Switching Model

\begin{tabular}{lll}
\hline Variables & Description & Measurement \\
\hline & Dependent: & \\
\hline
\end{tabular}

$\mathrm{SWITCH}_{i} \quad$ Company i switched to a new audit Binary variable $\mathrm{SWITCH}_{i}=1$ in case of auditor firm in the next period (year $\mathrm{t}+1$, switch, else $\mathrm{SWITCH}_{i}=0$ $\mathrm{t}+2$, or $\mathrm{t}+3$ )

\section{Independent:}

IGCOY $1_{i}$ : Initial going-concern opinion received in year $t$ by an auditor in the first year of his official mandate.

IGCOY2: Initial going-concern opinion received in year $\mathrm{t}$ by an auditor in the second year of his official mandate.

IGCOY $3_{i}$ : Initial going-concern opinion received in year $\mathrm{t}$ by an auditor in the last year of his official mandate.

RGCOY $1_{i}$ : $\quad$ Repeated going-concern opinion received in year $\mathrm{t}$ by an auditor in the first year of his official mandate.

RGCOY2: $\quad$ Repeated going-concern opinion received in year $t$ by an auditor in the second year of his official mandate.

RGCOY $3_{i}$ : $\quad$ Repeated going-concern opinion received in year $\mathrm{t}$ by an auditor in the last year of his official mandate.

DSCORE: Financial condition of the company. Discriminant score of company $\mathrm{i}$ in year $\mathrm{t}$

B6: $\quad$ Company $i$ has a Big 6 auditor or a non-Big 6 auditor in year $\mathrm{t}$

LNASSETS: Client size
Binary variable: IGCOY $1_{1}=1$ in case of an initial going-concern opinion in the first year of the auditor's official mandate, else IGCOY $1_{1}=0$

Binary variable: IGCOY $2_{\mathrm{i}}=1$ in case of an initial going-concern opinion in the second year of the auditor's official mandate, else IGCOY $2_{i}=0$

Binary variable: IGCOY $_{3}=1$ in case of an initial going-concern opinion in the last year of the auditor's official mandate, else IGCOY $3_{i}=0$

Binary variable: $R G C O Y 1_{i}=1$ in case of a repeated going-concern opinion in the first year of the auditor's official mandate, else $\mathrm{RGCOY} 1_{i}=0$

Binary variable: $R G C O Y 2_{i}=1$ in case of a repeated going-concern opinion in the second year of the auditor's official mandate, else RGCOY $2_{\mathrm{i}}=0$

Binary variable: $\mathrm{RGCOY} 3_{i}=1$ in case of a repeated going-concern opinion in the last year of the auditor's official mandate, else RGCOY $3_{i}=0$

General discriminant score (D-score) of Ooghe \& Vebaere's bankruptcy model developed for Belgian companies.

Binary variable: $\mathrm{B} 6 \mathrm{i}=1$ in case of a Big 6 auditor, else $\mathrm{B} 6_{i}=0$

Natural logarithm of total assets in year $t$

currently have a conservative auditor. Big 6 auditors tend to be more conservative given their larger liability exposure. Moreover, large auditors are more likely to resign because they face greater economic threats from litigation and/or reputation loss. ${ }^{12}$ This would result in a positive sign. low.

12. It is noted though that Breesch (2001) suggests the resignation rate of Belgian auditors is 
Third, auditor switching could be affected by client size. Some auditor switching studies find a negative relationship between auditor switching and size (Haskins and Williams [1990]; Krishnan [1994]). Smaller companies tend to move to large auditors as they grow and their needs change. For large companies, auditor switching is more costly (Williams [1988]). Moreover, fewer audit firms exist that can handle large companies since they are often geographically dispersed and involve complex transactions. I measure client size by the natural logarithm of total assets (LNASSETS). model:

Using logistic regression analysis, I estimate the following auditor switching

$$
\begin{aligned}
\text { SWITCH }_{i}= & \beta_{0}+\beta_{1} \text { IGCOY }_{i}+\beta_{2} \text { IGCOY }_{i}+\beta_{3} \text { IGCOY }_{i} \\
& +\beta_{4} \text { RGCOY }_{i}+\beta_{5} \text { RGCOY }_{i}+\beta_{6} \text { RGCOY }_{i} \\
& +\beta_{7} \text { DSCORE }_{\mathrm{i}}+\beta_{8} \text { B }_{i}+\beta_{9} \text { LNASSETS }_{i}+\varepsilon_{\mathrm{i}}
\end{aligned}
$$

\section{Results}

\subsection{Bankruptcy Model}

The three samples (bankrupt; financially stressed, non-bankrupt; and financially non-stressed, non-bankrupt) contain 392 observations each, or in total 1,176 companies. Of these 1,176 companies, 198 companies $(17 \%)$ receive a going-concern opinion. Of these 198 companies, only $53(27 \%)$ survive the first year. The three previous audit reports of the 198 companies are examined to identify companies with initial going-concern opinions. Of these 198 companies, 76 companies $(38.4 \%)$ receive a going-concern opinion for the first time. Of these 76 companies, only 27 companies $(35.5 \%)$ survive the following year. Of the 122 companies with a repeated going-concern opinion, only 26 companies $(21.3 \%)$ survive the subsequent year.

Table 4 presents the descriptive statistics of the control variables and Table 5 presents the Pearson correlation matrix. Table 4 shows that, in comparison with non-bankrupt firms, companies one year prior to bankruptcy have significantly lower D-scores and significantly delay the annual general meetings and the submission of financial statements. Most companies are located in Flanders, but the presence of Walloon companies is significantly higher in the sample of bankrupt companies. Finally, soon-to-be bankrupt firms disclose significantly more bad news in their annual reports.

The results of the bankruptcy model can only be used to assess the impact of a going-concern opinion on the probability of bankruptcy if the going-concern opinion variable is exogenous (Pryor and Terza [2001]). Therefore, it is checked whether the going-concern opinion variables are correlated with the regression error term, resulting in biased regression estimates (Greene [2000]). To test for endogeneity bias, the following procedure is followed. First, I estimate the goingconcern opinion model to compute the generalized residuals of the going-concern 
TABLE 4

\section{Descriptive Statistics-Bankruptcy Model}

\begin{tabular}{|c|c|c|c|}
\hline Variables & $\begin{array}{l}\text { Bankrupt Companies } \\
\qquad(\mathrm{N}=392)\end{array}$ & $\begin{array}{l}\text { Non-Bankrupt Companies } \\
\qquad(\mathrm{N}=784)\end{array}$ & $\begin{array}{l}\text { Pearson } \chi^{2} \\
(p \text {-value*) }\end{array}$ \\
\hline IGCO & $\begin{array}{l}\text { IGCO: } 12.8 \% \\
\text { No IGCO: } 87.2 \%\end{array}$ & $\begin{array}{l}\text { IGCO: } 3.4 \% \\
\text { No IGCO: } 96.6 \%\end{array}$ & $\begin{array}{l}37.028 \\
(0.000)\end{array}$ \\
\hline RGCO & $\begin{array}{l}\text { RGCO: } 24.5 \% \\
\text { No RGCO: } 75.5 \%\end{array}$ & $\begin{array}{l}\text { RGCO: } 3.3 \% \\
\text { No RGCO: } 96.7 \%\end{array}$ & $\begin{array}{l}126.007 \\
(0.000)\end{array}$ \\
\hline LOC & $\begin{array}{l}\text { Flanders: } 65.1 \% \\
\text { Wallonia: } 34.9 \%\end{array}$ & $\begin{array}{l}\text { Flanders: } 71.0 \% \\
\text { Wallonia: } 29.0 \%\end{array}$ & $\begin{array}{l}4.395 \\
(0.036)\end{array}$ \\
\hline PAR2 & $\begin{array}{l}\text { Info.: } 17.1 \% \\
\text { No info.: } 82.9 \%\end{array}$ & $\begin{array}{l}\text { Info.: } 5.7 \% \\
\text { No info.: } 94.3 \%\end{array}$ & $\begin{array}{l}28.860 \\
(0.000)\end{array}$ \\
\hline PAR3 & $\begin{array}{l}\text { Info.: } 5.2 \% \\
\text { No info.: } 94.8 \%\end{array}$ & $\begin{array}{l}\text { Info.: } 2.1 \% \\
\text { No info.: } 97.9 \%\end{array}$ & $\begin{array}{l}6.294 \\
(0.012)\end{array}$ \\
\hline ADINFO & $\begin{array}{l}\text { No info.: } 35.5 \% \\
\text { Adinfo }=1: 34.5 \% \\
\text { Adinfo }=2: 20.6 \% \\
\text { Adinfo }=3: 9.4 \%\end{array}$ & $\begin{array}{l}\text { No info.: } 58.3 \% \\
\text { Adinfo }=1: 29.6 \% \\
\text { Adinfo }=2: 10.2 \% \\
\text { Adinfo }=3: 1.9 \%\end{array}$ & $\begin{array}{l}60.708 \\
(0.000)\end{array}$ \\
\hline ART103/104 & $\begin{array}{l}\text { Info.: } 23.7 \% \\
\text { No info.: } 76.3 \%\end{array}$ & $\begin{array}{l}\text { Info.: } 8.5 \% \\
\text { No info.: } 91.5 \%\end{array}$ & $\begin{array}{l}37.829 \\
(0.000)\end{array}$ \\
\hline Variables & $\begin{array}{c}\text { Bankrupt Companies } \\
\text { Mean Rank (Sum of } \\
\text { Ranks) }\end{array}$ & $\begin{array}{c}\text { Non-Bankrupt Companies } \\
\text { Mean Rank (Sum of } \\
\text { Ranks) }\end{array}$ & $\begin{array}{c}\text { Mann-Whitney U } \\
\text { (p-value*) }\end{array}$ \\
\hline DSCORE & $\begin{array}{l}373.41 \\
(146377) \\
\text { 25th percentile: }-1.68 \\
\text { median: }-0.59 \\
\text { 75th percentile: } 0.07\end{array}$ & $\begin{array}{l}696.04 \\
(545699) \\
\text { 25th percentile: }-0.21 \\
\text { median: } 0.58 \\
75 \text { th percentile: } 1.59\end{array}$ & $\begin{array}{l}69349 \\
(0.000)\end{array}$ \\
\hline GMDELAY & $\begin{array}{l}679.57 \\
(266391) \\
25 \text { th percentile: } 5 \\
\text { median: } 6 \\
75 \text { th percentile: } 6\end{array}$ & $\begin{array}{l}542.96 \\
(425684) \\
25 \text { th percentile: } 5 \\
\text { median: } 5 \\
75 \text { th percentile: } 6\end{array}$ & $\begin{array}{l}117964 \\
(0.000)\end{array}$ \\
\hline SUBMLAG & $\begin{array}{l}623.21 \\
(244298) \\
25 \text { th percentile: } 22 \\
\text { median: } 33 \\
75 \text { th percentile: } 69.50\end{array}$ & $\begin{array}{l}571.15 \\
(447778) \\
\text { 25th percentile: } 22 \\
\text { median: } 30 \\
\text { 75th percentile: } 48\end{array}$ & $\begin{array}{l}140058 \\
(0.006)\end{array}$ \\
\hline
\end{tabular}

*One-tailed test.

Variable definitions:

\begin{tabular}{|c|c|}
\hline IGCO & $=$ initial going-concern opinion \\
\hline RGCO & $=$ repeated going-concern opinion \\
\hline LOC & $=$ location of client company in Wallonia \\
\hline PAR2 & $\begin{array}{l}=\text { information in paragraph } 2 \text { "Important Events after the Closing of the Fiscal Year" of } \\
\text { the annual report of the Board of Directors }\end{array}$ \\
\hline PAR3 & $\begin{array}{l}=\text { information in paragraph } 3 \text { "Circumstances That Can Influence Significantly the De- } \\
\text { velopment of the Company" of the annual report of the Board of Directors }\end{array}$ \\
\hline ADINFO & $\begin{array}{l}=\text { additional information (general information on the economic situation, description of } \\
\text { the prospects of the company, description of actions and/or measures that will be taken) } \\
\text { in the annual report of the Board of Directors }\end{array}$ \\
\hline & $\begin{array}{l}=\text { application of Article } 103 / 104 \text { of Belgian Company Law is disclosed in the annual } \\
\text { report of the Board of Directors }\end{array}$ \\
\hline RE & $=$ general discriminant score \\
\hline LAY & $=$ delay of the annual general meeting of shareholders \\
\hline LAG & $=$ submission lag of the financial statements to the Belgian National Bank \\
\hline
\end{tabular}




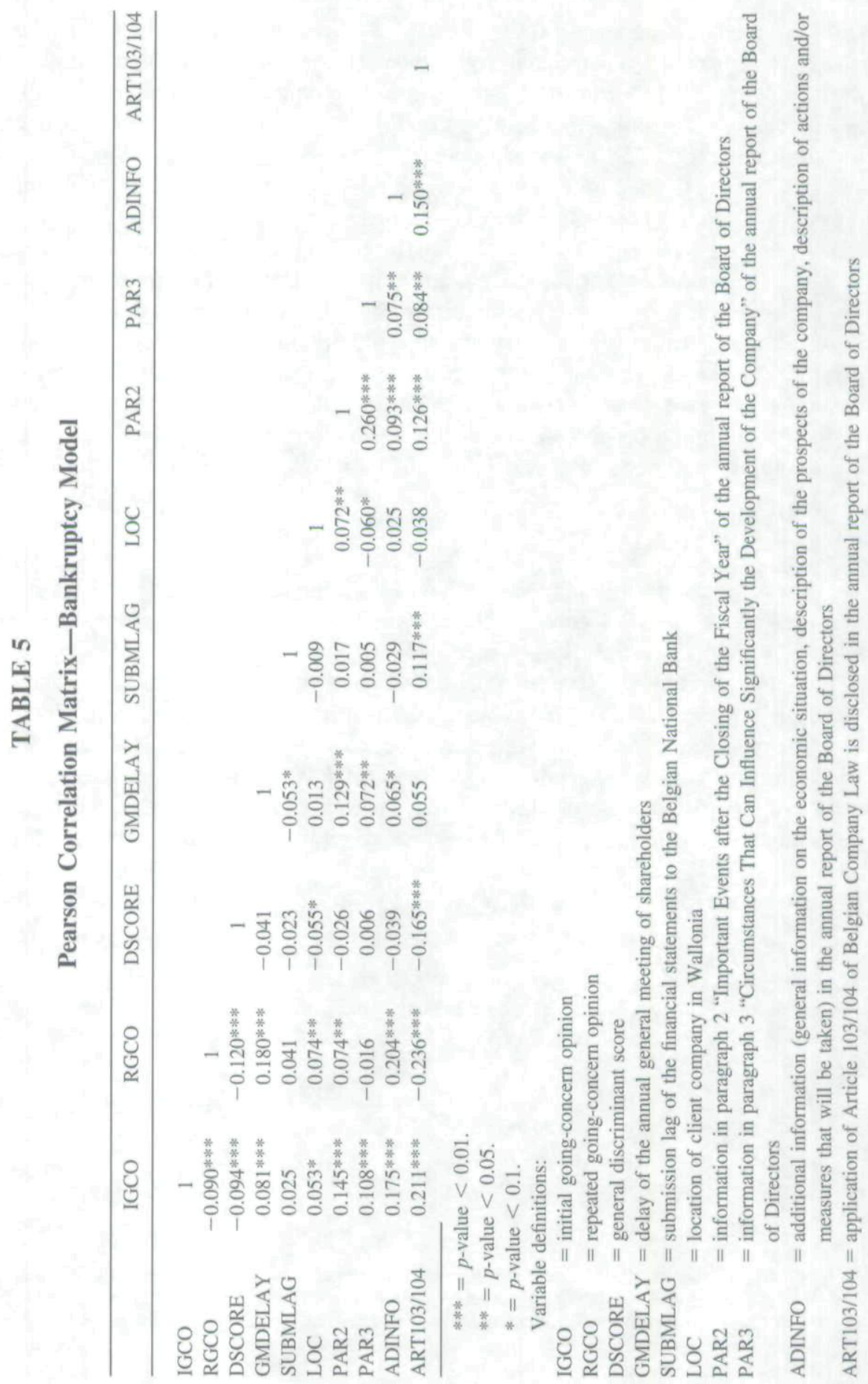


opinion variable (Gourieroux et al. [1987]). ${ }^{13.14}$ Subsequently, I include these generalized residuals as an additional explanatory variable in the bankruptcy model. If the coefficient of the residuals is significant, the going-concern opinion variables are endogenous. In unreported results, I find the coefficient of the residual variable insignificant $(\mathrm{p}=0.872)$, so the hypothesis of no endogeneity bias cannot be rejected. Hence, the bankruptcy model can be used to assess the impact of a goingconcern opinion on the probability of bankruptcy.

As can be seen from Table 6 , the coefficients of both the initial and repeated going-concern opinion variables are significant $(\mathrm{p}<0.01)$. This is consistent with the hypothesis that a going-concern opinion significantly increases the probability of bankruptcy. Table 6 further shows that the following variables significantly increase the likelihood of bankruptcy: bad financial condition, a delay of the annual general meeting of shareholders, a delay of the submission of the financial statements, location in an economically weaker region, important post year-end events, and additional bad news disclosed in the annual report of the Board of Directors. ${ }^{15}$

\subsection{Switching Model}

The samples of financially stressed, non-bankrupt and financially non-stressed, non-bankrupt companies contain 392 cases each or, in total, 784 companies, of which 73 companies $(9.31 \%)$ switched auditors.

Table 7 presents the results of the univariate analysis. The Pearson correlation matrix is presented in Table 8 . Table 9 presents the logistic regression results.

The results of both the univariate and logistic regression analysis show auditor switching is related to the year of mandatory term in which a going-concern opinion is given. In particular, companies switch auditors significantly more when they have received an initial or repeated going-concern opinion in the last year of the auditor's official mandate. An initial or repeated going-concern opinion in the first or second year does not result in a higher likelihood of auditor switching. ${ }^{16}$ This

13. The model for going-concern opinions is specified with the following independent variables: financial condition, delay of the annual general meeting, submission lag of the annual accounts, location of the client company, auditor type, auditor switch, length of the auditor-client relationship, year of auditor mandate, audit fee, recent client loss, and bad news in the annual report of the Board of Directors.

14. The generalized residuals are derived from the first order conditions that define the maximum likelihood estimates and are calculated as follows:

$$
e_{g}=\frac{(y-\hat{p}) f(-x \hat{\beta})}{\hat{p}(1-\hat{p})} \text { where } \hat{p}=1-F\left(-x^{\prime} \hat{\beta}\right)
$$

15. Company size (measured by natural logarithm of total assets) has no significant multivariate effect on bankruptcy.

16. A univariate analysis of auditor's reporting behavior shows that auditors issue less initial though significantly more repeated going-concern opinions in the last year of their mandate as opposed to the first two years. When tested in a multivariate way, there are no significant differences in auditor reporting behavior between the three years of the mandate, either for an initial or for a repeated goingconcern opinion. 
TABLE 6

Logistic Regression Results-Bankruptcy Model

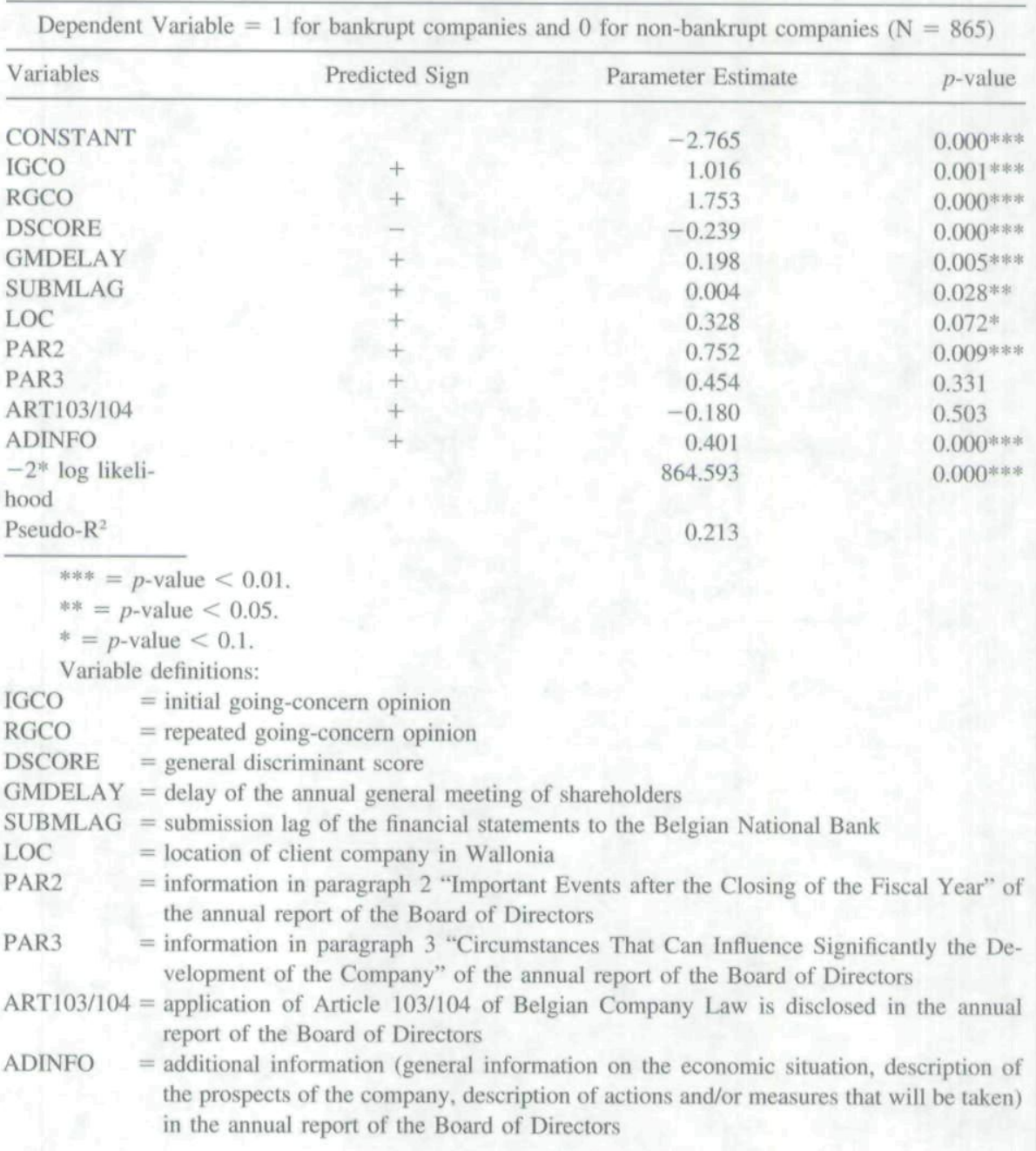

is also illustrated in Figure 1. This finding suggests clients apply greater pressure in the final year of their mandate and are not able to mount a credible threat in earlier years. For the control variables, I find no significant differences between companies that switch auditors and companies that do not switch. ${ }^{17}$

17. It is noted that there is no multivariate effect of change in client size and change in financial condition on auditor switching. 
TABLE 7

\section{Descriptive Statistics-Auditor Switching Model}

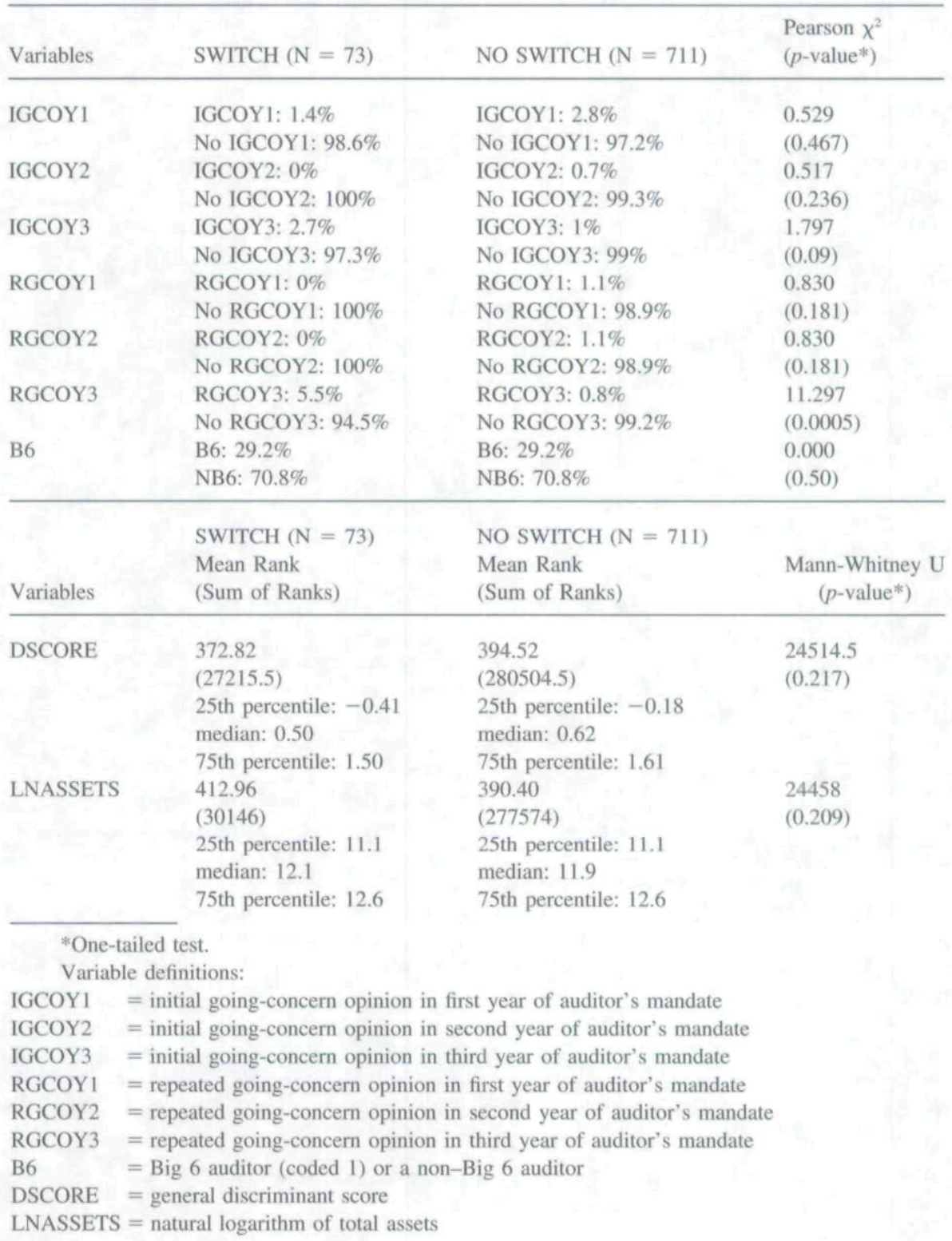




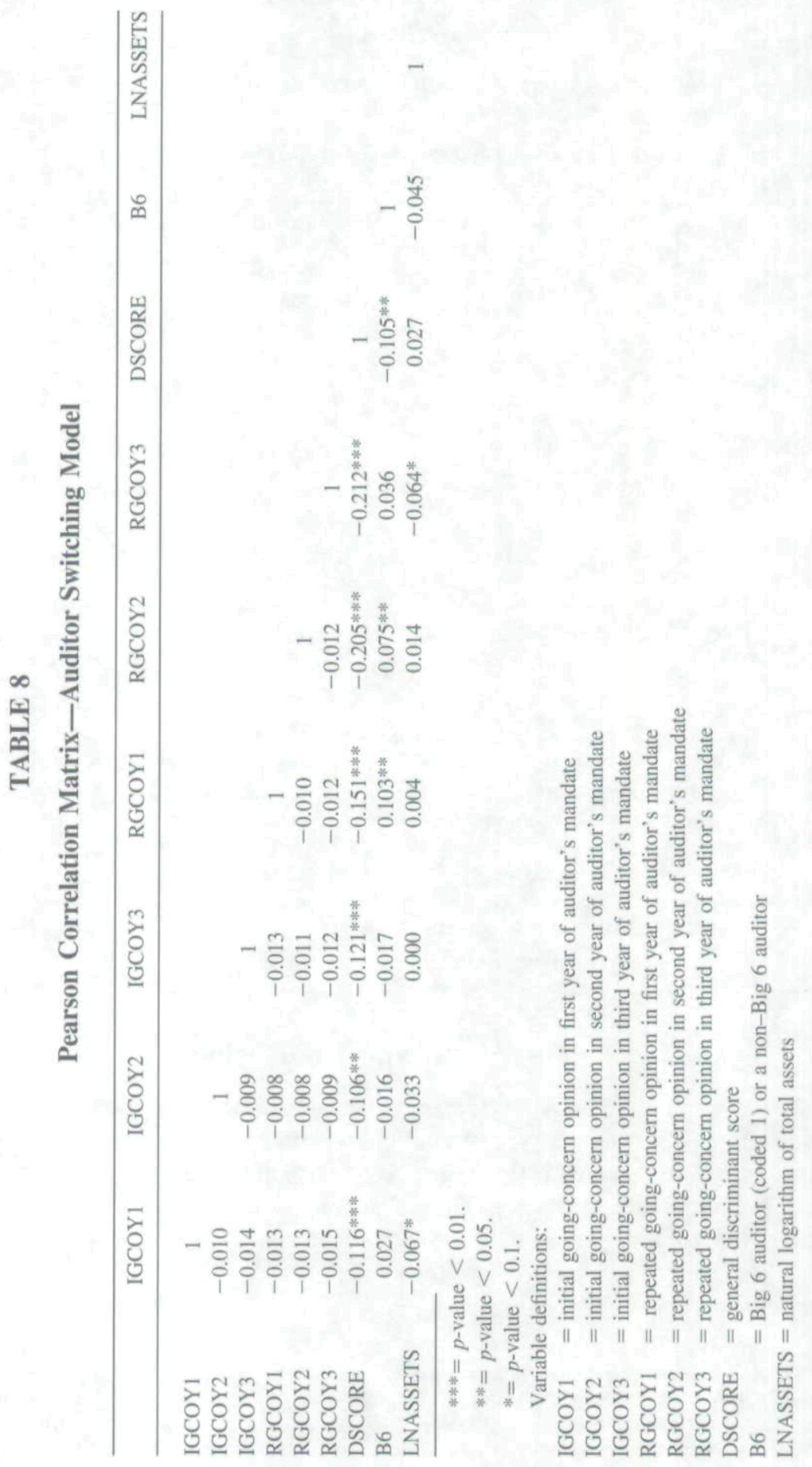


TABLE 9

\section{Logistic Regression Results-Auditor Switching Model}

Dependent Variable $=1$ for companies that switched auditors and 0 for companies that did not switch auditors $(\mathrm{N}=784)$

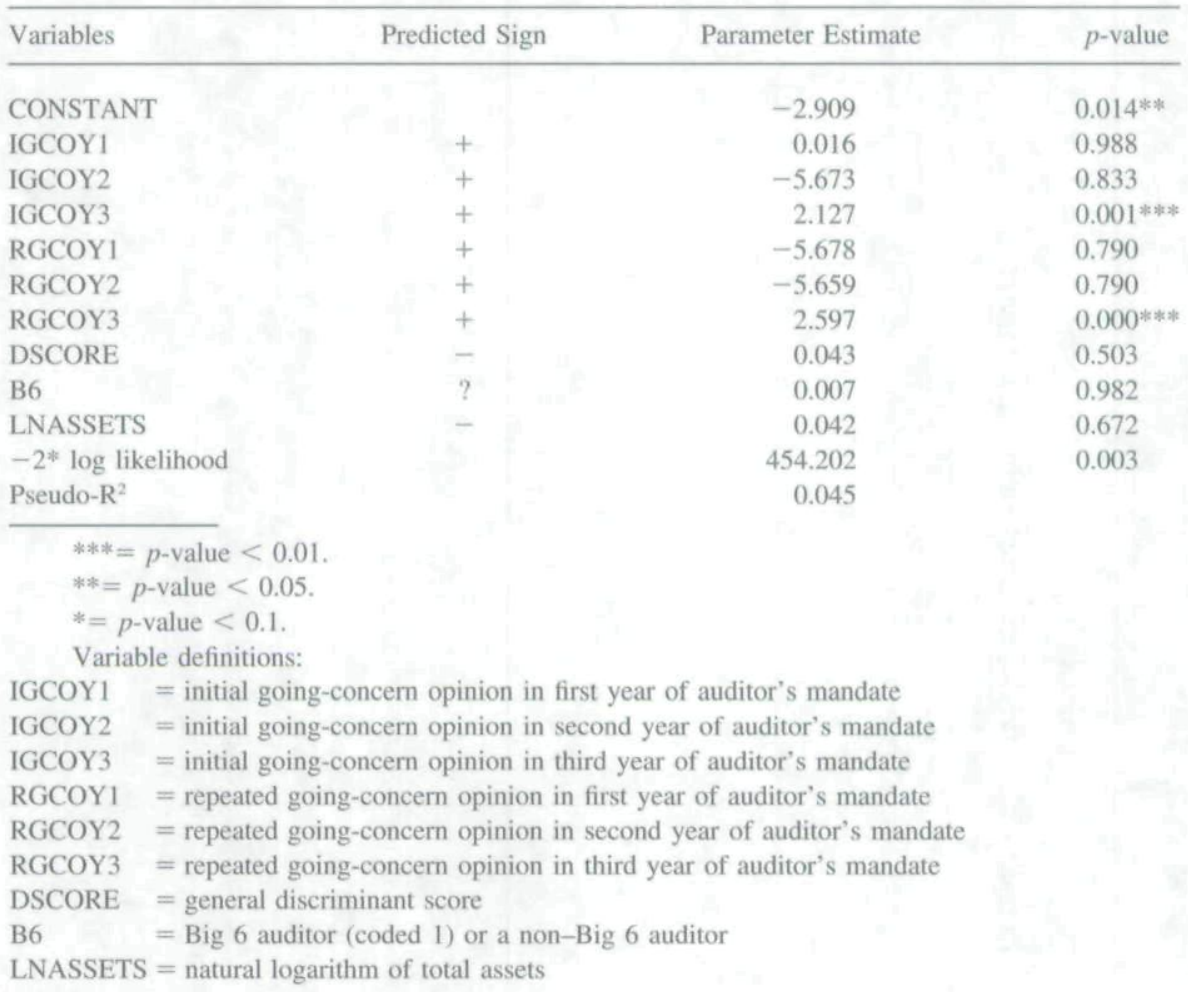

\section{Discussion and Conclusions}

This paper investigates the impact of a going-concern opinion on audit loss resulting from client bankruptcy or auditor switching. The results of the empirical analysis are consistent with the hypothesis that both initial and repeated goingconcern opinions increase the likelihood of impending bankruptcy. This finding suggests the audit report has informational value for the users of the financial statements, even in a country where corporate financing is dominated by banks and other financial institutions. ${ }^{18}$

18. An alternative method for testing the information content of audit opinions is an event study approach. Given the small number of Belgian companies that are listed and the fact that no listed firm went bankrupt in the period under study (1992-1996), it was not possible to examine the market reaction to going-concern disclosure announcements. 
FIGURE 1

\section{Auditor Switching and Going-Concern Opinions}

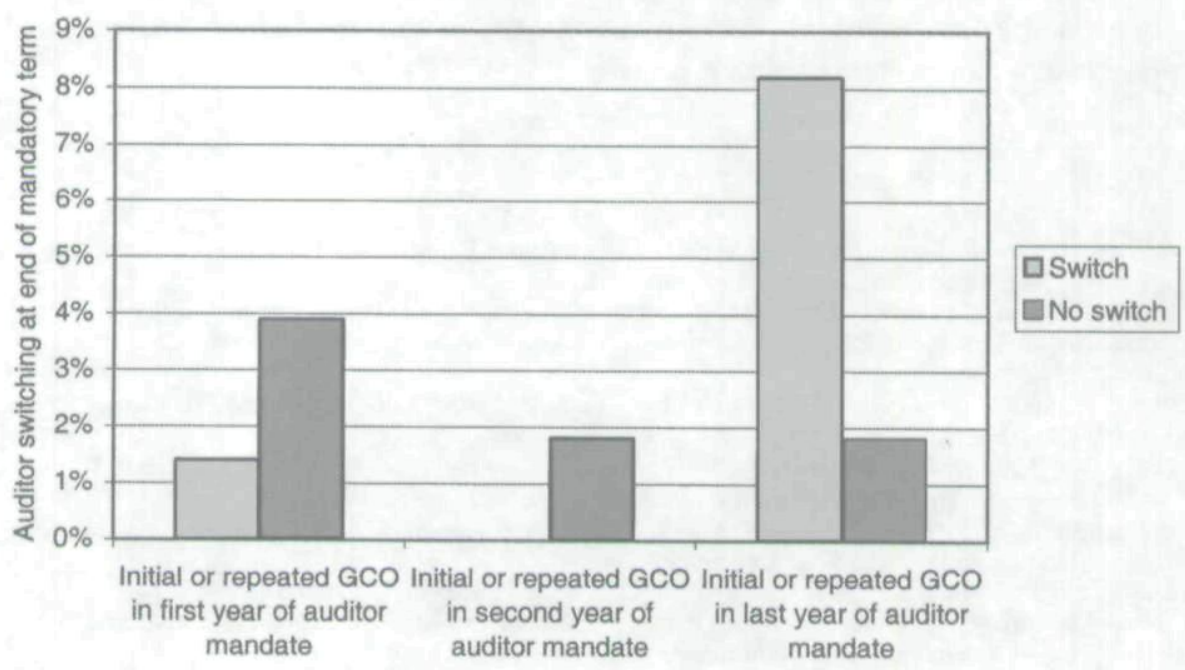

This paper addresses key technical problems of examining the self-fulfilling prophecy effect but is subject to several caveats. Although I control for a correlation between unobserved bankruptcy determinants and going-concern opinions and I control for most publicly observable indicators of distress, I cannot eliminate the omitted variable problem (e.g., I do not control for press coverage). Moreover, it is not possible to determine what would have happened to firms that received going-concern opinions had they not received them. Nor is it possible to randomly select firms that will receive a going-concern opinion in a controlled environment (Citron and Taffler [1992]).

My results provide further evidence that companies surviving a going-concern opinion are significantly more likely to switch auditors in the subsequent year. This finding is consistent with the results of Lennox (2000). In addition, I find that the effect of both initial and repeated going-concern opinions on auditor switching only occurs when going-concern opinions are given in the last year of official audit mandates. Indeed, clients are more than four times as likely to switch auditors at the end of the mandatory term if they receive a going-concern opinion in the final year, compared to any other year. This suggests the regulatory mandate of three years affects the way clients pressure auditors with a loss of future audit fees. A limitation of this study is that no distinction is made between auditor resignations and auditor dismissals. Belgian Company Law does not require companies to disclose the initiating party to an auditor change and in practice it is not disclosed. However, there is evidence that the resignation rate of auditors in Belgium is low (Breesch [2001]).

Finally, I analyze the impact of a going-concern opinion on the probability of 
bankruptcy and on the probability of auditor switching. Further research can investigate the impact of a going-concern opinion on other events (e.g., merger, voluntary liquidation) or on the auditor's reputation. The analysis of the economic effects and effectiveness of different national regulations on auditor independence presents another avenue of future research.

\section{REFERENCES}

Addams, H., and B. Davis. 1994. "Privately Held Companies Report Reasons for Selecting and Switching Auditors." CPA Journal 64 (August): 38-41.

Beattie, V., and S. Fearnley. 1995. "The Importance of Audit Firm Characteristics and the Drivers of Auditor Change in UK Listed Companies." Accounting and Business Research 25 (100): 227239.

Block, H., and A. Jorissen. 1995. "Belgium: Individual Accounts." In Transnational Accounting. Edited by D. Ordelheide and KPMG. Macmillan: New York.

Boritz, J.E. 1991. The "Going-concern" Assumption: Accounting and Auditing Implications. Toronto: Canadian Institute of Chartered Accountants.

Breesch, D. 2001. "Referral as Explanatory Variable for Auditor Switching in the Belgian Audit Market." Ph.D. diss., Vrije Universiteit Brussel.

Buijink, W., S. Maijoor, R. Meuwissen, and A. van Witteloostuijn. 1996. The Role, Position, and Liability of the Statutory Auditor Within the European Union. Maastricht Accounting and Auditing Research and Education Center, Universiteit Maastricht.

Carcello, J.V., D.R. Hermanson, and H.F. Huss. 1997. "Research Notes: The Effect of SAS No. 59: How Treatment of the Transition Period Influences the Results." Auditing: A Journal of Practice and Theory 16 (Spring): 114-123.

Chow, C.W., and S.J. Rice. 1982. "Qualified Audit Opinions and Auditor Switching." The Accounting Review (April): 326-335.

Citron, D.B., and R.J. Taffler. 1992. "The Audit Report under Going-Concern Uncertainties: An Empirical Analysis." Accounting and Business Research 22: 337-345.

Citron, D.B., and R.J. Taffler. 2001. "Ethical Behaviour in the U.K. Audit Profession: The Case of the Self-Fulfilling Prohecy under Going-Concern Uncertainties." Journal of Business Ethics 29(4): 353-363.

Craswell, A.T. 1988. "The Association Between Qualified Audit Opinions and Auditor Switches." Accounting and Business Research 19 (Winter): 23-31.

DeAngelo, L.E. 1982. "Mandated Successful Efforts and Auditor Choice." Journal of Accounting and Economics 4(3): 171-203.

De Financieel Economische Tijd. 1996. "Warning for Going-Concern Problems Is a Delicate Task for the Auditor." August 23, 1996.

DeFond, M.L. 1992. "The Association Between Changes in Client Firms, Agency Costs and Auditor Switching." Auditing: A Journal of Practice and Theory 11 (Spring): 16-31.

DeFond, M.L., and K.R. Subramanyam. 1998. "Auditor Changes and Discretionary Accruals." Journal of Accounting and Economics 25: 35-67.

Eichenseher, J., and D. Shields. 1983. "The Correlates of a CPA-Firm Change for Publicly Held Corporations." Auditing: A Journal of Practice and Theory 2: 23-37.

Fried, D., and A. Schiff. 1981. "CPA Switches and Associated Market Reactions." The Accounting Review 56: 347-374.

George, C., J. Spiceland, and S. George. 1996. "A Longitudinal Study of the Going-Concern Audit Decision and Survival Time." Advances in Quantitative Analysis of Finance and Accounting 4: 77-103.

Gietzmann, M.B., and R. Quick. 1998. "Capping Auditor Liability: The German Experience.” Accounting, Organizations and Society 23 (January): 81-103.

Gourieroux, C., A. Monfort, E. Renault, and A. Trognon. 1987. "Generalized Residuals." Journal of Econometrics 34: 5-32.

Greene, W.H. 2000. Econometric Analysis. 4th edition. London: Prentice Hall International. 
Haskins, M.E., and D.D. Williams. 1990. "A Contingent Model of Intra-Big 8 Auditor Changes." Auditing: A Journal of Practice and Theory 9 (Fall): 55-74.

Hopwood, W., J.C. McKeown, and J. Mutchler. 1991. "Towards an Explanation of Auditor Failure to Modify the Audit Opinions of Audit Qualifications." Auditing: A Journal of Practice and Theory (Supplement): 1-13.

Hopwood, W., J.C. McKeown, and J. Mutchler. 1994. "A reexamination of Auditor Versus Model Accuracy within the Context of the Going-Concern Opinion Decision." Contemporary Accounting Research 10 (Spring): 409-431.

Kida, T. 1980. "An Investigation into Auditor's Continuity and Related Qualification Judgements." Journal of Accounting Research (Autumn): 506-523.

Kinney, W.R. 1994. "Audit Litigation Research: Professional Help Is Needed." Accounting Horizons (June): $80-86$.

Krishnan, J. 1994. "Auditor Switching and Conservatism.” The Accounting Review (January): 200-215.

Krishnan, J., and J. Krishnan. 1996. "The Role of Economic Trade-Offs in the Audit Opinion Decision: An Empirical Analysis." Journal of Accounting, Auditing \& Finance 11(4): 565-586.

Krishnan, J., J. Krishnan, and R. Stephens. 1996. "The Simultaneous Relation Between Auditor Switching and Audit Opinion: An Empirical Analysis." Accounting and Business Research 26 (Summer): 224-236.

Krishnan, J., and R. Stephens. 1995. "Evidence on Opinion Shopping from Audit Opinion Conservatism." Journal of Accounting and Public Policy 14: 179-201.

Lefebvre, C., and J. Flower. 1994. Belgium. European Financial Reporting Series. London: Routledge.

Lennox, C. 2000. "Do Companies Successfully Engage in Opinion-Shopping? Evidence from the UK." Journal of Accounting and Economics 29: 321-337.

Levinthal, D., and M. Fichman. 1988. "Dynamics of Interorganizational Attachments: Auditor-Client Attachments." Administrative Science Quarterly 33(3): 345-369.

Louwers, T.J., F.M. Messina, and M.D. Richard. 1999. "The Auditor's Going-Concern Disclosure as a Self-Fulfilling Prophecy: A Discrete-Time Survival Analysis.” Decision Sciences 30(3): 805823.

Maddala, G. 1991. “A Perspective on the Use of Limited Dependent and Qualititative Variables Models in Accounting Research." The Accounting Review 66(4): 788-807.

Matsumura, E., K. Subramanyam, and R. Tucker. 1997. "Strategic Auditor Behaviour and GoingConcern Decisions." Journal of Business Finance and Accounting 24 (July): 727-758.

Menon, K., and K.B. Schwartz. 1985. "Auditor Switches by Failing Firms." The Accounting Review (April): 248-261.

Menon, K., and D. Williams. 1991. "Auditor Credibility and Initial Public Offering." The Accounting Review 66(2): 313-332.

Mueller, G., H. Gernon, and G. Meek. 1994. Accounting: An International Perspective. New York: Irwin.

Mutchler, J.F. 1984. "Auditors' Perceptions of the Going-Concern Opinion Decision." Auditing: A Journal of Practice and Theory 3 (Spring): 17-30.

Mutchler, J.F. 1985. "A Multivariate Analysis of the Auditor's Going-Concern Opinion Decision." Journal of Accounting Research (Autumn): 668-682.

Nogler, G. 1995. "The Resolution of Auditor Going-Concern Opinions." Auditing: A Journal of Practice and Theory 14(2): 54-73.

Ooghe, H., P. Joos, and C. de Bourdeaudhuij. 1995. "Financial Distress Models in Belgium: The Results of a Decade of Empirical Research." International Journal of Accounting Education and Research 30 (Spring): 245-274.

Pryor, C., and J.V. Terza. 2001. "Are Going-Concern Audit Opinions a Self-Fulfilling Prophecy?" Working paper, University of Southern Maine.

Schwartz, K., and B. Soo. 1996. "Evidence of Regulatory Noncompliance with SEC Disclosure Rules on Auditor Changes." The Accounting Review 71(4): 555-573.

Teoh, S. 1992. "Auditor Independence, Dismissal Threats, and the Market Reaction to Auditor Switches." Journal of Accounting Research 30 (Spring): 1-23.

Tucker, R., and E. Matsumura. 1998. "Going-Concern Judgments: An Economic Perspective." Behavioural Research in Accounting 10: 179-218.

Williams, D.D. 1988. "The Potential Determinants of Auditor Change." Journal of Business, Finance and Accounting 15(2): 243-262. 
Copyright of Journal of Accounting, Auditing \& Finance is the property of Greenwood Publishing Group Inc.. The copyright in an individual article may be maintained by the author in certain cases. Content may not be copied or emailed to multiple sites or posted to a listserv without the copyright holder's express written permission. However, users may print, download, or email articles for individual use. 